\title{
Transinactivation of the epidermal growth factor receptor tyrosine kinase and focal adhesion kinase phosphorylation by dietary flavonoids: effect on invasive potential of human carcinoma cells
}

\author{
Lung-Ta Lee ${ }^{\mathrm{a}, \mathrm{f}, 1}$, Ying-Tang Huang ${ }^{\mathrm{a}, 1}$, Jiuan-Jiuan Hwang ${ }^{\mathrm{b}}$, Amy Y.-L. Lee ${ }^{\mathrm{c}}$, \\ Ferng-Chun Ke ${ }^{\mathrm{d}}$, Chang-Jen Huang ${ }^{\mathrm{a}}$, Chithan Kandaswami ${ }^{\mathrm{e}}$, \\ Ping-Ping H. Lee ${ }^{\mathrm{a}}$, Ming-Ting Lee ${ }^{\mathrm{a}, *}$ \\ anstitute of Biological Chemistry, Academia Sinica, Taipei, Taiwan \\ ${ }^{\mathrm{b}}$ Institute of Physiology, National Yang-Ming University, Taipei, Taiwan \\ ${ }^{\mathrm{c}}$ Duke University, Durham, NC 27708, USA \\ ${ }^{\mathrm{d}}$ Department of Zoology, National Taiwan University, Taipei, Taiwan \\ ${ }^{\mathrm{e}}$ Department of Medicine, SUNY at Buffalo, NY 14263, USA \\ ${ }^{\mathrm{f}}$ Department of Nutrition and Health, Toko University, Taipei, Taiwan
}

Received 29 August 2003; accepted 2 February 2004

\begin{abstract}
Focal adhesion kinase (FAK), a member of a growing family of structurally distinct protein tyrosine kinases (PTK), has been linked to specific phosphorylation events, and the elevation of FAK activity in human carcinoma cells correlated with increased invasive potential. Transactivation of the epidermal growth factor receptor (EGFR) tyrosine kinase activity is proposed to stimulate cell migration and the subsequent activation of downstream signaling pathways. Quercetin $(\mathrm{Qu})$ and luteolin $(\mathrm{Lu})$, are potent PTK inhibitors as well as putative chemopreventive agents. The present work, we demonstrate that Qu and Lu at concentration of $20 \mu \mathrm{M}$ transinactivated EGFR tyrosine kinase activity with marked reduction in phosphotyrosyl level of 170, 125, 65, 60 and $42 \mathrm{kDa}$ cellular proteins, and induced apoptosis in MiaPaCa- 2 cells. The $125 \mathrm{kDa}$ protein was further identified as a FAK by immunoprecipitation and immunoblotting analyses. Tumor cells treated with $\mathrm{Lu}$ or Qu dampened the phosphorylation of FAK. In addition, our data clearly demonstrated that tumor cells responded to Qu and Lu by parallel reductions in the levels of phosphorylated FAK and the secreted matrix metalloproteinase (MMP) that may lead to the suppression of invasive potential and cell migration in vitro. While the molecular mechanism of FAK regulation of MMP secretion in tumor cells remains unclear, our results suggested that blockade of the EGFR-signaling pathway may contributed to the net effect. As suggested in the current study, targeting EGFR and FAK with the objective of modulating their regulatory pathways could offer prospects for the treatment of EGFR-responsive cancers in the future.
\end{abstract}

(C) 2004 Elsevier Inc. All rights reserved.

Keywords: Epidermal growth factor receptor; Flavonoids; Focal adhesion kinase; Invasion; Matrix metalloproteinase

\section{Introduction}

Spread of cancer through metastasis represents one of the gravest dangers of the disease $[1,2]$. In human cancers,

Abbreviations: DMSO, dimethyl sulphoxide; EGF, epidermal growth factor; ECL, enhanced chemiluminescence; FAK, focal adhesion kinase; MMP, matrix metalloproteinase; PTK, protein tyrosine kinase; SDSPAGE, sodium dodecyl sulphate polyacrylamide gel electrophoresis

* Corresponding author. Tel.: +886-2-27855696;

fax: +886-2-27889759.

E-mail address: mtlee@gate.sinica.edu.tw (M.-T. Lee).

${ }^{1}$ Lung-Ta Lee and Ying-Tang Huang contributed equally to this work. the production of certain MMPs correlates with the development of the ability to invade neighboring tissues and metastasize to distal sites $[3,4]$. The MMPs are encoded by at least 20 genes [5]. The MMPs have been categorized into four subclasses based on substrate specificity: collagenases, gelatinases, stromelysins and membrane-type MMPs $[3,6]$. Collectively, MMPs degrade most components of the extracellular matrix. Tumor cells probably need more than one MMP, as well as more general degradative enzymes, to cross the tissue barriers they encounter in the process of metastasis. Altering the secretion and/or the suppression of the MMP activities in cancers would be 
<smiles>O=c1c(O)c(-c2ccc(O)c(O)c2)oc2cc(O)cc(O)c12</smiles>

Quercetin<smiles>O=c1cc(-c2ccc(O)c(O)c2)oc2cc(O)cc(O)c12</smiles>

Luteolin

Fig. 1. The chemical structures of $\mathrm{Qu}$ and $\mathrm{Lu}$.

expected to limit the metastatic potential by preventing the degradation of basement membranes and stromal connective tissues. Many drugs such as prostacyclin, ursolic acid and BB-94 have been tested both in animal models and in human clinical trials for their potential to prevent metastasis $[2,4,7]$.

EGFR is a cell surface glycoprotein composed of a single polypeptide chain $170 \mathrm{kDa}$ in molecular mass, which binds to EGF. EGFR and Erb2/HER/Neu2 are members of the type I growth factor family of polypeptide growth factor receptors whose overexpression shows a correlation with decreased disease-free survival and enhanced metastasis in advanced cancer conditions [8]. Activation of EGFR is believed to stimulate cell growth and migration through receptor phosphorylation and the subsequent activation of downstream signaling pathways including phospholipase $\mathrm{C} \gamma$, ERK/MAPK cascade and FAK. Studies have linked FAK, a non-receptor protein tyrosine kinase, to a variety of cellular signaling pathways for cell survival and cell cycle progression as well as for cell motility [9]. Evidence reveals an association of elevated FAK expression in human tumor cells with an increased cell invasion potential [10,11]. Tumor invasive ability is also correlated with increased cell migration [12]. In growing, integrin-stimulated, or migrating cells, FAK is highly phosphorylated at a number of residues in vivo $[13,14]$. In addition, the expression of PTEN, a tumor suppressor, leads to the dephosphorylation of FAK and inhibition of cell motility $[13,14]$. These observations indicate that elevated FAK expression may be useful as a marker for detecting tumor metastasis, and that FAK might be a rational therapeutic target for the prevention of the invasive process $[15,16]$.

The flavonoids, which are primarily benzo- $\gamma$-pyrone (phenylchromone) derivatives, comprise a very large class of naturally-occurring, low molecular weight polyphenolic plant compounds. The family includes flavanols and proanthocyanidins, flavanones, anthocyanidins, flavones, isoflavones and flavonols, among others [17]. Documented biologic effects of dietary flavonoids include anti-inflammatory, antiallergic, antimicrobial, hepatoprotective, antiviral, antithrombotic, cardioprotective, capillary strengthening, antidiabetic, anticarcinogenic and antineoplastic effects, among others [18-22]. The mechanisms for the potential chemopreventive action of the flavonoids await elucidation. Plant flavonoids possess the propensity to modify or modulate the activities of a host of enzyme systems critically involved in cell surface signal transduction, immune function, cellular transformation, tumor growth and metastasis [18-22]. Accumulating evidence indicates that certain flavonoids not only inhibit the growth of tumor cells $[18,23,24]$ but also induce cell differentiation [25]. The inhibitory effects of flavonoids on growth of malignant cells could be a consequence of their interference with the protein kinase activities involved in the regulation of cellular proliferation [18,26] and apoptosis [27]. In addition, the possible anti-metastatic properties of flavonoids, such as the suppression of the secretion of MMPs $[18,28]$ and modulation of epithelial cell migration [29] could also be relevant to their purported anticancer action.

Because EGF stimulates the growth of tumor cells, one would anticipate an inhibition in tumor cell growth as a result of a reduction in EGFR activity, as seen in response to flavonoids [14]. Agents exerting a decisively suppressive effect on EGFR kinase activity, their impact at the level of autophosphorylation would be the preferred site of action, because it would culminate in the blockade of the signaling pathway $[28,30]$. Our earlier findings indicated that Quercetin $(\mathrm{Qu})$ and luteolin $(\mathrm{Lu})$ decreased the basal and EGFstimulated phosphotyrosine level of 125, 110, 65 and $60 \mathrm{kDa}$ proteins $[18,28]$. Recent findings linking FAK with cell migration $[12,15,16,30]$ and the requirement for EGFR tyrosine kinase activation for this process prompted us to explore the requirement for FAK and EGFR in the processes of tumor cell survival and migration in more detail. We have unraveled the importance of FAK function in promoting EGF-stimulated cell motility through flavonoid treatment to reduce FAK expression and phosphorylation. A special focus of the current studies was to further establish the anticancer effects of the two pharmacologically active dietary flavonoids, $\mathrm{Qu}$ and Lu (Fig. 1).

\section{Materials and methods}

\subsection{Materials}

$\mathrm{Qu}$, was purchased from Nacalai Tesque (Kyoto, Japan). $\mathrm{Lu}$, was purchased from Extrasynthese (Genay, France). Wogonin (Wo) was obtained from Sigma (St. Louis, MO). 
The flavonoids were dissolved in DMSO and stored in the dark at a concentration of $100 \mathrm{mM}$. RPMI-1640, Dulbecco's Modified Eagle Medium, and fetal bovine serum were obtained from GIBCO (Grand Island, NY). EGF, anti-phosphotyrosine and anti-EGFR antibodies were purchased from Upstate (Lake Placid, NY). Rabbit anti-FAK was acquired from Santa Cruz Biotechnology (Santa Cruz, CA). The mouse anti-FAK-p-Y397 was purchased from BD Biosciences (San Diego, CA). Purified human MMP-2, MMP-9 and anti-MMP-2 and MMP-9 antibodies were purchased from Biogenesis (Sandown, $\mathrm{NH})$. ECL was obtained from Amersham (Buckinghamshire, UK).

\subsection{Cell growth experiments}

The MiaPaCa-2 (pancreas) and A431 (skin) tumor cell lines were obtained from the American Type Culture Collection (Rockville, MD). Cells were maintained at $37^{\circ} \mathrm{C}$ in a humidified atmosphere $(95 \%$ air and $5 \%$ $\mathrm{CO}_{2}$ ) and grown as monolayer in plastic tissue culture flasks containing Dulbecco's Modified Eagle Medium or RPMI-1640, supplemented with $10 \%$ fetal bovine serum, $100 \mathrm{units} / \mathrm{ml}$ penicillin and $100 \mu \mathrm{g} / \mathrm{ml}$ streptomycin (GIBCO) according to the recommendations of the American Type Culture Collection.

Cells growing in log phase were harvested by suspension in $0.25 \%$ trypsin-EDTA solution for $5 \mathrm{~min}$. The cells were then washed once with RPMI-1640 medium and resuspended at a concentration of $1 \times 10^{4}$ cells $/ \mathrm{ml}$ in a volume of $1.0 \mathrm{ml}$ RPMI-1640 medium in 24-well plates. The cells were incubated at $37^{\circ} \mathrm{C}$ for $24 \mathrm{~h}$ to allow attachment to plates, and flavonoids were added to obtain final concentrations of 10,20,50 and $100 \mu \mathrm{M}$. The cells were also treated with EGF at a concentration of $10 \mathrm{nM}$. Control wells contained DMSO at a final concentration of $0.1 \%$. For growth determination, cells from triplicate wells representing each treatment condition were harvested with $0.25 \%$ trypsin-EDTA and counted in a Coulter Counter (Coulter Electronics, Luton, England), and cell viability was determined using the dye exclusion method. Cell numbers were also determined using a colorimetric assay with the reduction of 3-(4,5-dimethylthiazol-2-yl)-2,5diphenyl tetrazolium bromide as the assessable end-point, as previously described [31].

\subsection{Preparation of cell lysates}

EGF- and flavonoid-treated cells were harvested and washed three times with PBS. The cells were then lysed in gold lysis buffer as previously described [32]. Insoluble material was collected by centrifugation at $12,000 \times g$ for $10 \mathrm{~min}$ at $4{ }^{\circ} \mathrm{C}$. The protein concentration was determined according to the method of Bradford [33] and adjusted to $2.0 \mu \mathrm{g} / \mu \mathrm{l}$. The samples were then divided into $50 \mu \mathrm{l}$ aliquots and stored at $-70{ }^{\circ} \mathrm{C}$ for further study.

\subsection{Total kinase activity assay}

The total kinase activity assays were performed as previously described [18]. Briefly, the reaction mixtures in a final volume of $80 \mu \mathrm{l}$ contained $50 \mu \mathrm{g}$ of cellular proteins in $20 \mathrm{mM}$ HEPES buffer, pH 7.4, $1.0 \mathrm{mM} \mathrm{MnCl}_{2}$, and 10 $100 \mu \mathrm{M} \mathrm{Qu}$ or Lu. The reaction mixtures were preincubated at room temperature for $2 \mathrm{~h}$ and then were chilled at $4{ }^{\circ} \mathrm{C}$ for $10 \mathrm{~min}$. The reaction was initiated by the addition of $[\gamma-$ ${ }^{32}$ P]ATP $(6-12 \times 106 \mathrm{cpm})$ and unlabeled ATP $(60 \mu \mathrm{M})$. After $5 \mathrm{~min}$, the reaction was stopped by pipetting $50 \mu \mathrm{l}$ aliquots of the reaction mixtures onto $2.3 \mathrm{~cm}$ diameter Whatman $3 \mathrm{MM}$ filter paper, which was immediately dropped into a solution of $10 \%$ trichloroacetic acid containing $10 \mathrm{mM}$ pyrophosphate. The filter papers were then washed sequentially with $10 \%$ trichloroacetic acid, 50, and $100 \%$ ethyl alcohol $(10 \mathrm{ml}$ each), and dropped into a beaker with $50 \mathrm{ml}$ of diethyl ether for $2 \mathrm{~min}$ and then dried in a fume hood. The radioactivity was measured in scintillation counter (Beckman Instruments, Fullerton, CA).

\subsection{Immunoprecipitation}

Cell lysates with equivalent amounts of proteins were incubated with anti-FAK antibodies $(1 \mu \mathrm{g} / \mathrm{ml})$ for $4 \mathrm{~h}$ at $4{ }^{\circ} \mathrm{C}$ with gentle shaking according to the manufacturer's recommendations. Immunocomplexes of FAK/anti-FAK antibodies were removed by centrifugation at $14,000 \times$ $g$ at $4{ }^{\circ} \mathrm{C}$ for $30 \mathrm{~min}$. The supernatants and precipitants were collected and subjected to total kinase assay as previously described [34].

\subsection{Gel electrophoresis, western blotting, and autoradiography}

The kinase assay reaction mixtures described above were also subjected to SDS-polyacrylamide gel electrophoresis (SDS-PAGE) to examine further changes of cellular protein phosphorylation in response to EGF and flavonoids. The kinase reactions were terminated by the addition of $50 \mu 12 \times$ sample buffer $(0.5 \mathrm{M}$ Tris-HCl, pH 6.9; $2 \%$ SDS; $20 \%$ glycerol; $0.01 \%$ bromophenol) followed by boiling for 3 min. The reaction products were then electrophoresed on 3-18\% linear gradient SDS-polyacrylamide gels according to the method of Laemmli [35] and were dot blotted on nitrocellulose paper. Proteins were then electrophoretically transferred to nitrocellulose membranes as previously described [36] and then autoradiographed with Kodak XOmat AR film (Kodak, Rochester, NY). The intensities of the phospho-proteins were determined using a densitometer.

\subsection{Immuno-blot analysis of EGFR, phosphotyrosine protein, and FAK}

The proteins separated on SDS-PAGE were electrophoretically transferred to nitrocellulose membrane according 
to the method of Towbin [36]. The electrophoretic blots were blocked in PBS containing 5\% BSA for $2 \mathrm{~h}$ at room temperature, and then were rinsed in PBS three times and incubated for $2 \mathrm{~h}$ at room temperature with primary antibody appropriately diluted in $1 \% \mathrm{BSA} / \mathrm{PBS}$. The primary antibodies used in this study included: mouse monoclonal IgG-anti human EGFR, mouse monoclonal IgG-anti phosphotyrosine, mouse monoclonal IgG-anti human FAK and rabbit anti-MMP-2 and anti-MMP-9. The nitrocellulose membranes were then extensively washed three times for 10 min each in TBST, and incubated with the secondary antibody (goat anti-rabbit or rabbit anti-mouse $\operatorname{IgG}$ ) conjugated with horseradish peroxidase. The membranes were subsequently washed three times with TBST and twice with Triethanolamine buffered saline (TBS). Bands were detected with ECL reagents on Kodak BioMax film (Kodak, Rochester, NY).

To ascertain whether the phosphotyrosyl $125 \mathrm{kDa}$ protein was indeed an FAK, anti-FAK polyclonal antibody was used to immunoprecipitate FAK protein. EGF and/or flavonoids treated and untreated cell lysates with equivalent amounts of proteins were incubated with anti-FAK polyclonal antibodies $(1 \mu \mathrm{g} / \mathrm{ml})$ for $4 \mathrm{~h}$ at $4{ }^{\circ} \mathrm{C}$ with gentle shaking, according to the manufacturer's recommendations. FAK/anti-FAK antibody complexes were removed by centrifugation at $14,000 \times g$ at $4{ }^{\circ} \mathrm{C}$ for $20 \mathrm{~min}$. The immunoprecipitates were washed three times with PBS containing $1 \%$ Trixton-100 and subjected to immunoblotting analyses for FAK. In addition, the same immunoprecipitates were subjected to total kinase assay as described above.

\subsection{Detection and characterization of MMPs by gelatin zymography}

The amounts of MMPs secreted from tumor cells treated with $10 \mathrm{nM}$ EGF and $20 \mu \mathrm{M}$ flavonoids were measured using gelatin zymography [37]. In brief, samples of conditioned media and cell lysates were subjected to electrophoresis on $3-18 \%$ linear gradient SDS-PAGE copolymerized with $0.1 \%$ porcine skin gelatin. The volume of each medium sample analyzed was normalized according to its cell numbers. Electrophoresis was performed under non-reducing conditions in $25 \mathrm{mM}$ Tris, $192 \mathrm{mM}$ glycine, and $0.1 \%$ SDS at $15 \mathrm{~mA} / \mathrm{gel}$ during stacking and at $12 \mathrm{~mA} /$ gel during separation. After electrophoresis, gels were first washed twice for $30 \mathrm{~min}$ in $2.5 \%$ Triton X-100 to remove SDS, and then twice in reaction buffer $(50 \mathrm{mM}$ Tris, $\mathrm{pH} 8.0$, containing $5 \mathrm{mM} \mathrm{CaCl}_{2}, 0.02 \% \mathrm{NaN}_{3}$ ) for an additional $30 \mathrm{~min}$. The gels were then incubated in reaction buffer at $37{ }^{\circ} \mathrm{C}$ for $18 \mathrm{~h}$, and then stained with $0.25 \%$ Coomassie brilliant blue R-250 in $10 \%$ acetic acid/20\% ethanol for $1 \mathrm{~h}$ and destained in the same solution without dye. A clear zone on the gel indicates the presence of gelatinase activity. Gelatinase activity was quantified using a densitometer.

\subsection{In vitro chemo-invasion assay}

In vitro invasiveness was investigated according to a procedure described previously [38], with modification. In brief, 24-well Transwell units with $8 \mathrm{~mm}$ pore size polycarbonate filters (Becton Dickinson, Franklin Lake, NJ) were coated with $0.1 \mathrm{ml}$ of $0.8 \mathrm{mg} / \mathrm{ml}$ Englebreth-HolmSwarm sarcoma tumor extract, named EHS Matrigel, at room temperature for $1 \mathrm{~h}$. The EHS matrigel consists of reconstituted basement membrane substances. These filters were then air dried at room temperature, thus forming a continuous thin layer on top of the filter. The lower compartment contained $0.6 \mathrm{ml}$ laminin $(20 \mathrm{mg} / \mathrm{ml})$ as a chemoattractant or RPMI-1640 medium as a negative control. A431 or MiaPaCa- 2 cells $\left(10^{5}\right.$ cells per $0.2 \mathrm{ml}$ of RPMI-1640 containing $0.1 \%$ BSA) were placed in the upper compartment and incubated with or without either flavonoids or EGF at $37{ }^{\circ} \mathrm{C}$ for $72 \mathrm{~h}$ in a humidified atmosphere of $95 \%$ air $/ 5 \% \mathrm{CO}_{2}$. Following incubation, the filters were fixed with $3 \%$ glutaraldehyde in PBS and stained with crystal violet. Cells on the upper surface of the filter were removed by wiping with a cotton swab, and cells that penetrated through the Matrigel to the lower surface of the filter were counted under a microscope at $\times 200$ magnification. Each treatment was assayed in triplicate, and two independent experiments were performed.

\subsection{Wound healing assay}

MiaPaCa- 2 cells $\left(2 \times 10^{6}\right)$ were plated onto fibronectin coated $(5 \mu \mathrm{g} / \mathrm{ml}) 6$-well culture plates in complete growth medium. After $24 \mathrm{~h}$, the monolayer of cells was wounded by manual scratching with a pipette tip [39], washed with PBS, photographed with phase contrast using Olympus IX70 camera (Tokyo, Japan) and placed into complete medium with or without either flavonoids or EGF at $37{ }^{\circ} \mathrm{C}$ in a humidified atmosphere of $95 \%$ air $/ 5 \% \mathrm{CO}_{2}$. Matched pair marked wound regions were photographed again after $48 \mathrm{~h}$ of treatment.

\subsection{Immunofluoresence staining}

MiaPaCa- 2 cells $\left(10^{4} /\right.$ well) were plated onto fibronectin-coated $(10 \mu \mathrm{g} / \mathrm{ml})$ glass coverslips and grown in RPMI1640 containing $10 \%$ fetal bovine serum overnight. The cells were then treated with $20 \mu \mathrm{M} \mathrm{Qu}, \mathrm{Lu}$ and/or $10 \mathrm{nM}$ EGF for $4 \mathrm{~h}$ prior to fixation with $3.7 \%$ paraformaldehyde in PBS. Control cells received DMSO vehicle at a final concentration of $0.1 \%$. Cells were permeabilized with the ice-cold methanol for $15 \mathrm{~min}$, washed in PBS three times and then blocked with $1 \%$ BSA in PBS for $2 \mathrm{~h}$ at room temperature. Primary mouse anti-FAK-p-Y397 antibody was diluted (1:200) in $0.5 \%$ BSA in PBS and incubated for $2 \mathrm{~h}$ at room temperature. After two washes in $0.25 \%$ TBST and three washes in PBS, coverslips were incubated for $1 \mathrm{~h}$ with goat anti-Mouse IgG-Cy3 (1: 200) (Jackson Immu- 
noResearch Laboratories, Inc. West Glove, PA). After two washes in $0.25 \%$ TBST and 3 washes in PBS, the coverslips were then air-dried and mounted with Slow Fade (Molecular Probes, Eugene, OR) mounting media. Photomicrographs were prepared by using a laser scanning confocal microscope (MMRC 600 Model, Bio-Rad Laboratories Inc., Hercules, CA) or an Olympus IX70-FLA inverted fluorescence microscope equipped with the spot system (Diagnostic Instruments, Inc., Sterling Height, MI) and assembled by PhotoShop program (Adobe Systems Inc., San Jose, CA).

\subsection{Statistics}

Results are expressed as means \pm S.E.M.s of three to six independent experiments. Statistical significance of differences between two groups was determined by mean of an unpaired Student's $t$-tests. A probability of $P<0.05$ was considered significant.

\section{Results}

\subsection{Effects of quercetin and luteolin on kinase activitiess of cellular proteins of MiaPaCa-2 cells}

Due to the dramatic inhibitory effect of Qu and Lu on cell proliferation [18,28], we attempted to determine the effects of various concentrations of $\mathrm{Qu}$ and $\mathrm{Lu}$ on protein kinase activity in MiaPaCa-2 cellular proteins. Wo was served as a reference in the present study. The protein kinase activity was measured as incorporation of $\left[{ }^{32} \mathrm{P}\right]$ phosphate from $[\gamma$ $\left.{ }^{32} \mathrm{P}\right] \mathrm{ATP}$ into trichloroacetic acid-insoluble materials. Both Qu and Lu dose-dependently $(10-100 \mu \mathrm{M})$ inhibited Mia$\mathrm{PaCa}-2$ cellular protein kinase activity, and the estimated $\mathrm{IC}_{50}$ of $\mathrm{Qu}$ and Lu were 14 and $22 \mu \mathrm{M}$, respectively (Fig. 2). As expected, Wo exhibited little effect on kinase activity of MiaPaCa-2 cellular proteins. In addition, the anti-phosphotyrosyl antibody dot blotting assay showed that $\mathrm{Qu}$ and $\mathrm{Lu}$ dose-dependently suppressed tyrosine kinase activity (Fig. 3). These results further demonstrated that both Qu and Lu directly inhibited the tyrosine kinase activity of MiaPaCa-2 cellular proteins. Our previous works and present data suggest that both $\mathrm{Qu}$ and $\mathrm{Lu}$, at a concentration of $20 \mu \mathrm{M}$, could block approximately $50 \%$ of the growth and kinase activity of MiaPaCa- 2 cells. Therefore, the concentration of $20 \mu \mathrm{M}$ for $\mathrm{Qu}$ and $\mathrm{Lu}$ was used throughout our present study.

\subsection{Effects of quercetin and luteolin on basal and EGF-induced cellular protein phosphorylation}

It is well known that EGF activates EGFR tyrosine kinase activity and promotes cell growth. Furthermore, consistent with our previous study, EGF stimulated total kinase activities and increased the phosphotyrosyl protein

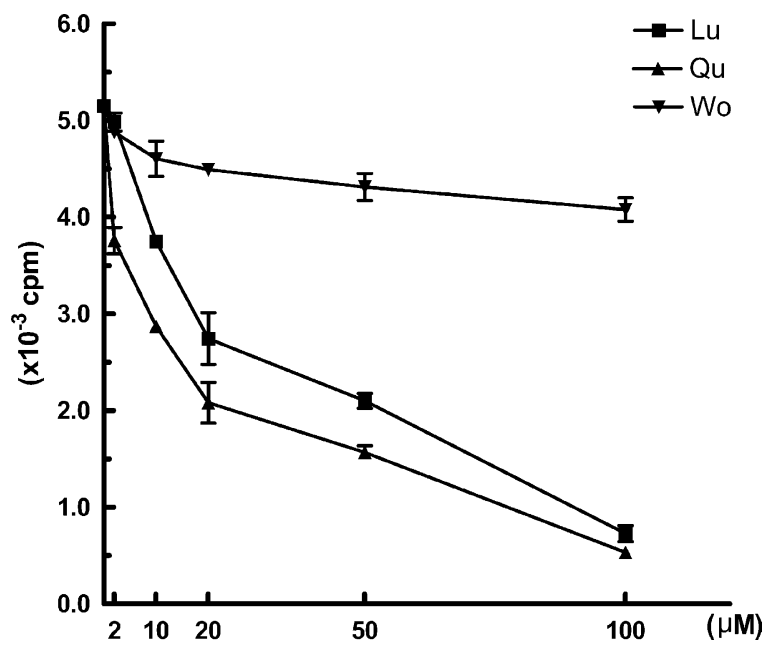

Fig. 2. Effects of various concentrations of $\mathrm{Qu}, \mathrm{Lu}$ and Wo upon the protein kinase activity of MiaPaCa-2 cellular proteins. Cell lysates of $50 \mu \mathrm{g} / 80 \mu \mathrm{l}$ of proteins were preincubated with various doses of $\mathrm{Qu}, \mathrm{Lu}$ or Wo, respectively, in the presence of $\left[\gamma-{ }^{32} \mathrm{P}\right] \mathrm{ATP}$. The radioactivities were counted as described in Section 2. All determinations were made in triplicate. The plot is the representative of three independent experiments, all of which gave similar results.

level of A431 cellular proteins compared to the control [18]. To further test our previous findings that $\mathrm{Qu}$ and $\mathrm{Lu}$ blocked EGFR tyrosine kinase activity and its signal pathway in other tumor cell lines, we expanded our study in

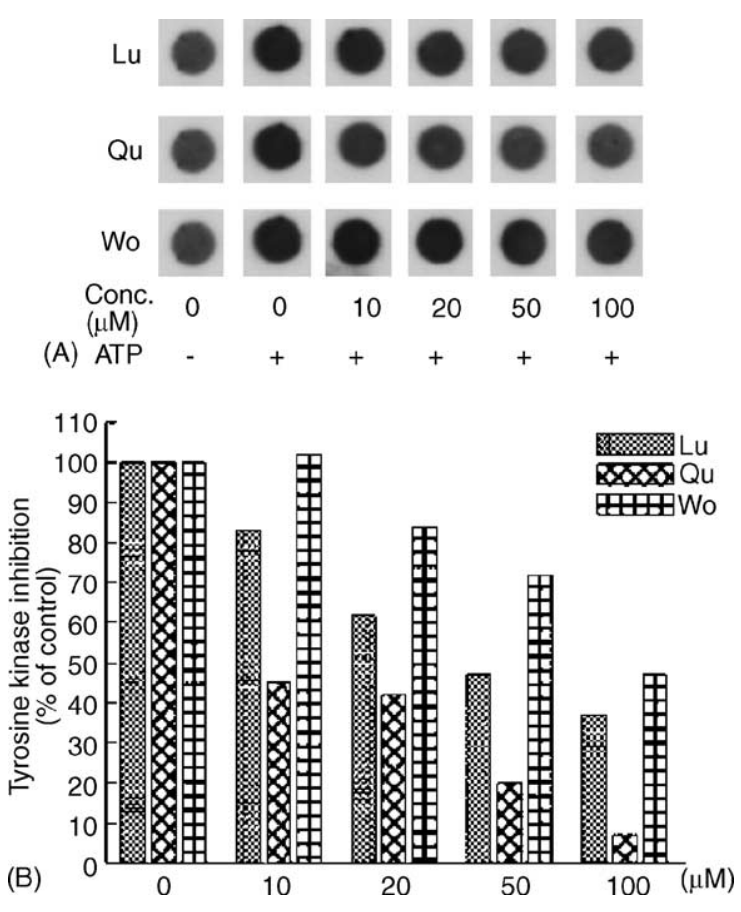

Fig. 3. Effect of Qu and Lu upon tyrosine phosphorylation of MiaPaCa-2 cellular protein. Cell lysates of $50 \mu \mathrm{g} / 80 \mu \mathrm{l}$ of proteins were preincubated with various doses of $\mathrm{Qu}, \mathrm{Lu}$ or Wo, respectively, in the presence or absence of $60 \mu \mathrm{M}$ ATP. Five microliters of each reaction mixtures were subjected to the dot blotting assay. Anti-phosphotyrosine antibody and ECL were used to detect the phosphotyrosine protein level (panel A). Quantitative changes of tyrosine phosphorylation were estimated based on the percentage of the control value in the presence of ATP (panel B). Similar results were obtained in three independent experiments. 


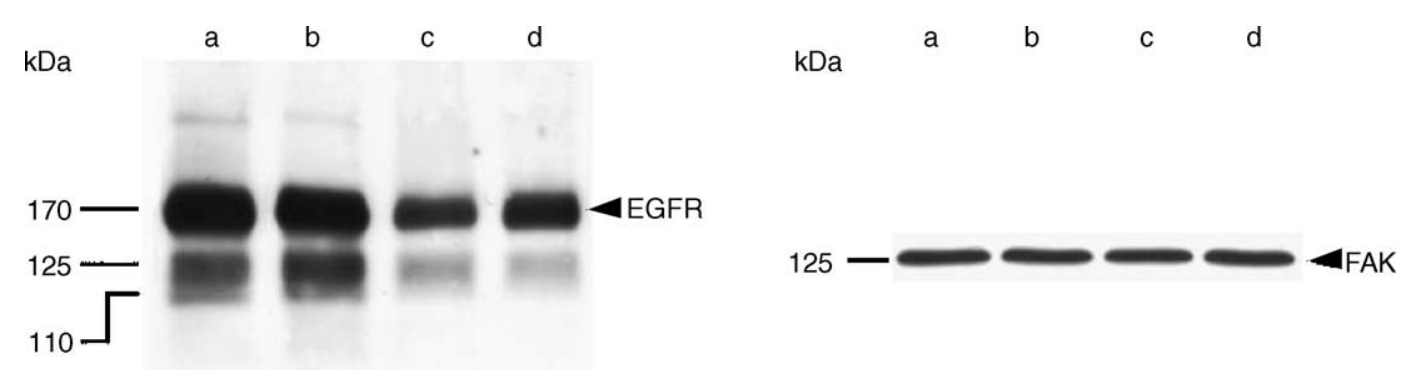

(A)

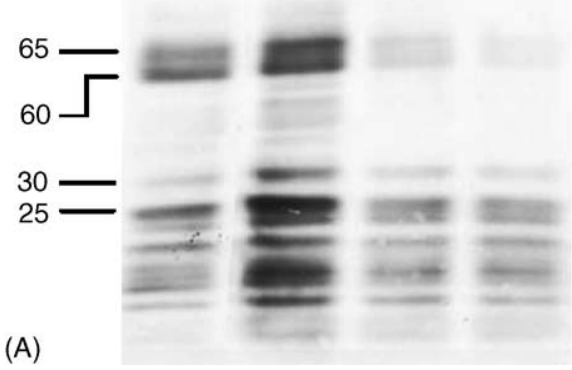

(B)

Fig. 4. In vitro effect of $\mathrm{Qu}$ and $\mathrm{Lu}$ upon the tyrosine kinase activity of MiaPaCa-2 cellular proteins. Cell lysates of $120 \mu \mathrm{g}$ of protein, in the presence of $60 \mu \mathrm{M}$ ATP were incubated with Qu, Lu $(20 \mu \mathrm{M})$ or EGF $(100 \mathrm{nM})$ in a total volume of $160 \mu \mathrm{l}$ for $10 \mathrm{~min}$. Each reaction mixtures of $60 \mu \mathrm{l}$ was subjected to immunoblotting analysis. Lanes: a, control; b, EGF; c, Qu; d, Lu. Anti-phosphotyrosine protein antibody was used to detect phosphotyrosyl protein (panel A). Anti-FAK antibody was used to detect FAK. Similar amounts of FAK band were observed in all four lanes (panel B), while the phosphorylation levels were quite varied (panel A).

MiaPaCa-2 pancreatic tumor cell lines. Preincubation of MiaPaCa-2 cellular proteins with $100 \mathrm{nM}$ EGF for $1 \mathrm{~h}$ consistently increased the tyrosine phosphorylation of 170 , 125, 110, 65, 60, 44, 30 and $25 \mathrm{kDa}$ protein bands (Fig. 4, panel A, lane b). Pre-treatment of cellular proteins with either $20 \mu \mathrm{M} \mathrm{Qu}$ or $\mathrm{Lu}$ attenuated the tyrosine phosphorylation of all protein bands described above, except for the 30 and $25 \mathrm{kDa}$ bands, which showed no detectable changes compared to the control (Fig. 4, panel A, lanes c and d). The results also showed that $\mathrm{Qu}$ and $\mathrm{Lu}$ independently inhibited the autophosphorylation of $170 \mathrm{kDa}$ EGFR (Fig. 4, panel A, lanes c and d).

In addition, we observed that the phosphotyrosyl protein level of the $125 \mathrm{kDa}$ band was elevated by EGF and decreased by $\mathrm{Qu}$ and $\mathrm{Lu}$. We employed two additional approaches to identify whether this band was an FAK. The first approach used immunoblotting. The same blot was immunoblotted with anti-phosphotyrosine antibody was then reprobed with anti-FAK antibody. The results showed that the $125 \mathrm{kDa}$ band was immunoreactive with both antibodies (Fig. 4A and B). In the second approach, cell lysates were first immunoprecipitated with anti-FAK polyclonal antibodies, and the immunoprecipitates were then immunoblotted with another mouse anti-FAK antibody. The results further confirmed that the identity of the $125 \mathrm{kDa}$ band was indeed FAK (data not shown).

\subsection{Effects of quercetin and luteolin on basal and EGF-induced metastasis-associated MMPs}

EGF has been previously shown to stimulate the secretion of MMPs in A431 cells [18]. To investigate the effect of $\mathrm{Qu}$ and $\mathrm{Lu}$ on basal and EGF-induced secretion of MMPs involved in invasion/metastasis of cancer cells, culture conditioned media were collected from MiaPaCa-2 cells treated with $20 \mu \mathrm{M}$ flavonoids or $10 \mathrm{nM}$ EGF for $24 \mathrm{~h}$. Gelatinase activities were assessed using gelatin zymography and scanning densitometry. A representative zymogram is shown in Fig. 5A. The relative percentage change of gelatinase activity was determined based on the density value of the control group. Control MiaPaCa-2 cells secreted two major gelatinases of 92 and $72 \mathrm{kDa}$ (Fig. 5A, lane a) as well as a group of lower molecular weight gelatinases in the range from 50 to $65 \mathrm{kDa}$. Both Qu and Lu greatly reduced the basal secretion of the $92 \mathrm{kDa}$ gelatinase by $-70 \pm 8$ and $-82 \pm 5 \%$, respectively (Fig. 5A, lanes c and d), while EGF slightly increased the secretion of the $92 \mathrm{kDa}$ gelatinase by $+10 \pm$ $3 \%$ (Fig. 5A, lane b) and the $50 \mathrm{kDa}$ gelatinase by $+35 \pm$ $6 \%$. Equivalent levels of $72 \mathrm{kDa}$ secretion were observed in all treatments compared to control (Fig. 5A). Qu and Lu also offset EGF-stimulated secretion of $92 \mathrm{kDa}$ gelatins (Fig. 5A, lanes e and f). Lu also exerted a strong inhibitory effect on secretion of 60-65 kDa bands (Fig. 5A, lane d). $\mathrm{Qu}$ and $\mathrm{Lu}$ appeared to decrease the secretion of the $56 \mathrm{kDa}$ by $-32 \pm 6$ and $-45 \pm 5 \%$ and the $50 \mathrm{kDa}$ by $-82 \pm 7$ and $-76 \pm 8 \%$ bands, respectively. The secreted gelatinases were further characterized according to the biochemical dependence of the enzymes and their immunoreactivities. Addition of the MMP inhibitor 1,10-phenanthroline at the concentration of $5 \mathrm{mM}$ (Fig. 5B) or $10 \mathrm{mM}$ EDTA (data not shown) abolished the activity of all gelatinases. Trypsin was observed as a positive reference, indicating proteolytic activity in the absence or presence of 1,10-phenanthroline 

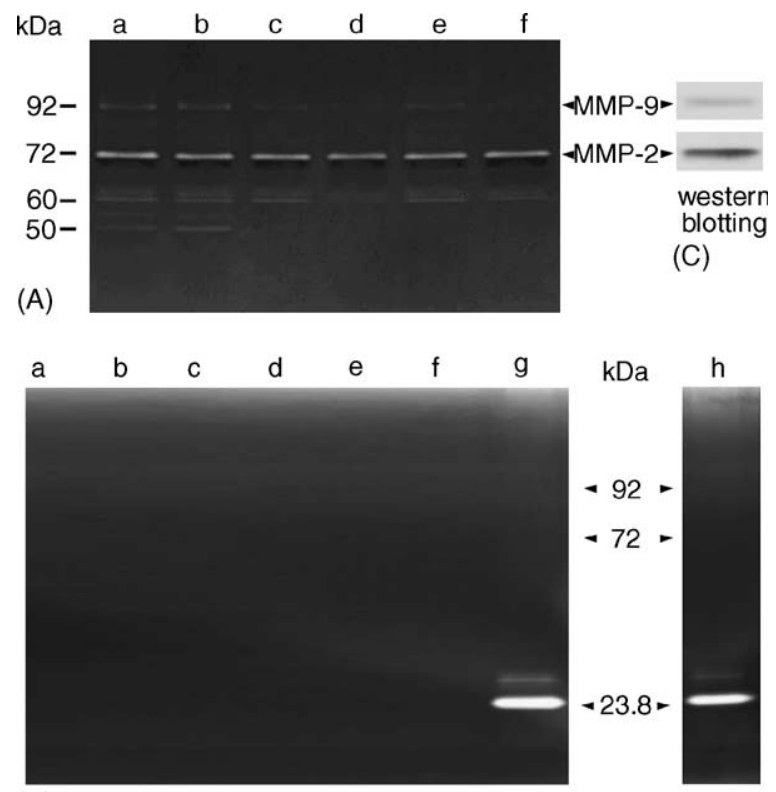

(B)

Fig. 5. Effects of Qu, Lu and EGF on the secretion of MMPs in MiaPaCa-2 cells. Cells at $50 \%$ confluence were treated with $20 \mu \mathrm{M} \mathrm{Qu}$ or $\mathrm{Lu}$, and/or $10 \mathrm{nM}$ EGF in serum free medium for $24 \mathrm{~h}$. The conditioned media were collected and normalized according to cell numbers prior to gelatin zymography analysis. Representative zymograms in the absence (panel A) or presence (panel B) of $5 \mathrm{mM}$ of the MMP inhibitor 1,10-phenanthroline during substrate buffer incubation. Lanes: a, vehicle control; b, EGF; c, Qu; $\mathrm{d}, \mathrm{Lu}$; e, EGF + Qu; f, EGF + luteolin; g and h, trypsin, a serine protease, was not inhibited by 1,10-phenanthroline. Immunoblotting analyses using anti-MMP-9 and MMP-2 antibodies indicated that the identity of the 92 and $72 \mathrm{kDa}$ gelatinases were MMP-9 and MMP-2, respectively. The zymograms (panels A and B) and immunoblots (panel C) are representative of three separate experiments performed in duplicate.

(Fig. 5B). Immunoblotting analysis revealed that the $92 \mathrm{kDa}$ gelatinase was MMP-9 and the $72 \mathrm{kDa}$ gelatinase was MMP-2 (Fig. 5C). We also performed immunoprecipitation using anti-MMP-9 and MMP-2 antibodies to remove the MMPs prior to zymography, and no detectable MMP-9 and MMP-2 were observed in this analysis (data not shown).

\subsection{Effects of quercetin and luteolin on basal and EGF-induced invasive activity}

Because it is widely accepted that secreted MMPs can influence the migratory as well as the invasive activity of cancer cells, Qu and Lu were tested for their effects on the invasive behavior of EGF-stimulated MiaPaCa-2 cells using an in vitro invasion assay. Representative micrographs of Transwell filters are shown in Fig. 6A. MiaPaCa2 cells treated with $20 \mu \mathrm{M}$ of $\mathrm{Qu}$ or $\mathrm{Lu}$ for $48 \mathrm{~h}$ significantly inhibited the invasive activity by about 44 and $53 \%$, respectively, compared with the control (Fig. 6B) EGF markedly promoted cell invasion by $61 \%$ (Fig. 6B), and Qu and Lu partially suppressed the EGF-induced invasive activity of MiaPaCa-2 cells by about 33 and 54\%, respectively (Fig. 6B).

\subsection{Effects of quercetin and luteolin on MiaPaCa-2 cell migration}

To investigate flavonoid and EGF effect on cell migration, in vitro wound healing assays were performed. The MiaPaCa- 2 cells were grown to the same density in serum free medium in six-well culture plates, and then the cell monolayer was wounded with a pipette tip (Fig. 7, panel a). After $24 \mathrm{~h}$ in the absence (panel b) or presence (panel e) of $10 \mathrm{nM}$ of EGF, MiaPaCa- 2 cells exhibited cell reorientation responses along the wounded edge margin and had migrated into the wound area. Cells treated with $20 \mu \mathrm{M} \mathrm{Qu}$ (panel c) or Lu (panel d) exhibited only limited cell reorientation responses along the wounded edge and did
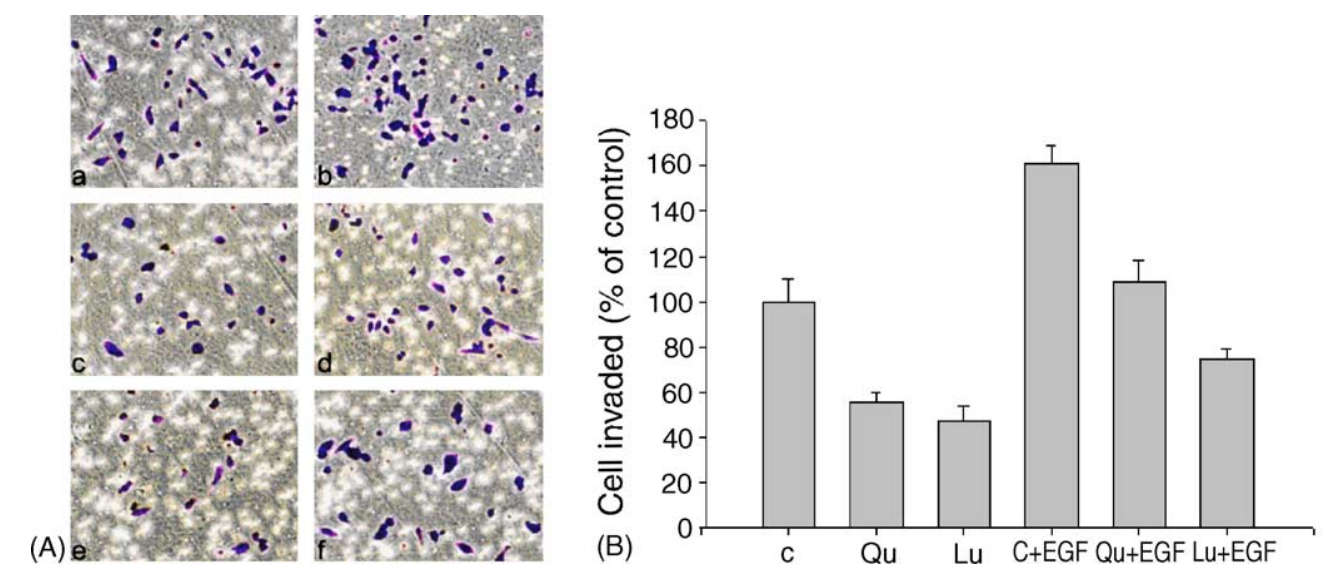

Fig. 6. Effect of Qu, Lu and EGF on invasive activity of MiaPaCa-2 cells. The in vitro invasion assay was performed using $24-w e l l$ Transwell units with an $8 \mu \mathrm{M}$ porosity polycarbonate filter coated with the reconstituted basement membrane EHS Matrigel. MiaPaCa- 2 cells $\left(2 \times 10^{5}\right.$ cells/ $\left.0.4 \mathrm{ml}\right)$ were placed in the upper compartment, and treated with $20 \mu \mathrm{M} \mathrm{Qu}$, or Lu, and/or $10 \mathrm{nM}$ EGF for $48 \mathrm{~h}$ in the presence of serum. At the end of culture, the filters from the Transwell units were fixed and stained with crystal violet. The number of cells that penetrated through the Matrigel to the lower surface of the filters was determined by microscopy. Panel A, representative photographs of the cells that invade Matrigel: a, vehicle control; b, EGF; c, Qu; d, Qu + EGF; e, Lu; f, Lu + EGF. Panel B, each bar represents mean ( \pm S.E.) percentage ( \pm S.E.M.) of invaded cells relative to the control value expressed as $100 \%$. Two independent experiments were performed in triplicate. 

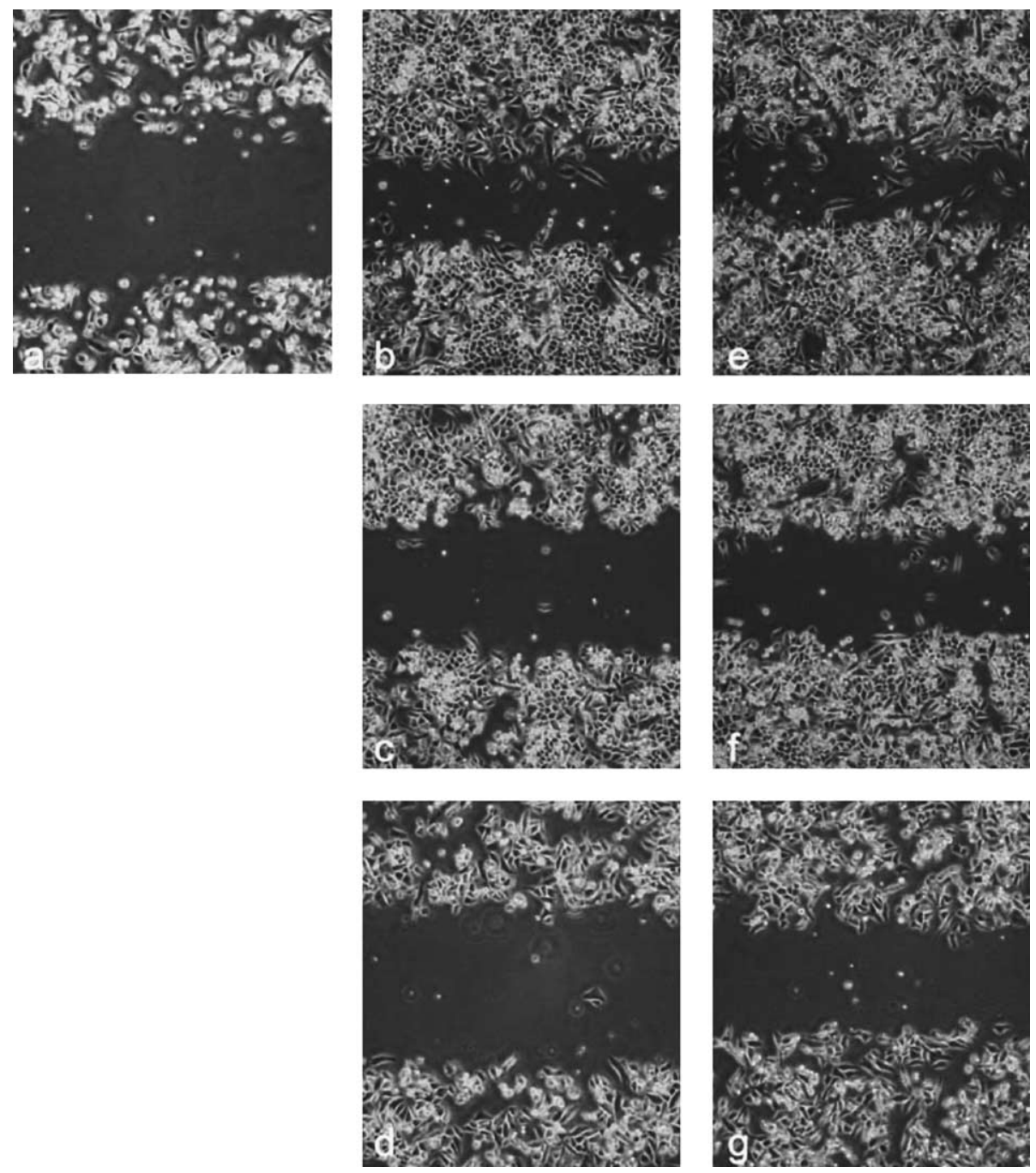

Fig. 7. Effect of Qu, Lu and EGF on wound healing of MiaPaCa-2 cells. MiaPaCa-2 cells $\left(2 \times 10^{5}\right)$ were plated onto 6-wells and allowed to grow in the presence of $10 \%$ fetal bovine serum. After $24 \mathrm{~h}$, a wound was created by scratching with a pipet tip (panel a) and the cells were then allowed to migrate into the wound area in the presence of $10 \%$ fetal bovine serum. After cells were treated without (panel b), or with $20 \mu \mathrm{M} \mathrm{Qu}$ (panel c), $20 \mu \mathrm{M} \mathrm{Lu}(\mathrm{panel} \mathrm{d}$ ) and $10 \mathrm{nM}$ EGF (panel e) or the combination of $20 \mu \mathrm{M}$ Qu and $10 \mathrm{nM}$ EGF (panel f), or $20 \mu \mathrm{M} \mathrm{Lu}$ and $10 \mathrm{nM}$ EGF (panel g) for additional $48 \mathrm{~h}$, phase contrast images were taken to assess cell migration.

not efficiently repopulate the open space as compared to the control (panel b). In addition, Qu and Lu partially suppressed the EGF-induced migration activity of MiaPaCa-2 cells (Fig. 7, panels $f$ and g).

\subsection{Effects of quercetin and luteolin on FAK expression, phosphorylation and subcellualr localization}

To study the association between Qu- and Lu-mediated reduction of FAK expression and FAK phosphorylation with the inhibition of EGF-stimulated signaling events, we examined the levels of FAK expression and relative levels of FAK tyrosine phosphorylation of MiaPaCa- 2 cells. Two approaches were employed: first, MiaPaCa-2 cells were treated with $10 \mathrm{nM}$ EGF in serum-free medium for 2, 12, and $24 \mathrm{~h}$, after which cell lysates were analyzed. Using the immunoblotting technique with anti-FAK and anti-FAK-pY397 antibodies, we observed that EGF time-dependently increased FAK protein expression and FAK phosphotyrosine levels (Fig. 8A). In the second approach, the lysates obtained from MiaPaCa- 2 cells treated with $20 \mu \mathrm{M} \mathrm{Qu}, \mathrm{Lu}$ and/or $10 \mathrm{nM}$ EGF for $24 \mathrm{~h}$ were subjected to immunoblotting analyses. Qu and Lu greatly reduced FAK protein phosphorylation by 61 and $27.7 \%$, respectively (Fig. 8B, lanes $\mathrm{b}$ and $\mathrm{c}$ ). To determine if FAK phosphorylation could be reversed by EGF, MiaPaCa-2 cells treated with $\mathrm{Qu}$ and $\mathrm{Lu}$ for $24 \mathrm{~h}$ were then replaced in fresh medium containing $10 \mathrm{nM}$ EGF for $24 \mathrm{~h}$. FAK protein expression was elevated to about 125 and $120 \%$ of control in MiaPaCa-2 cells (Fig. 8B, lanes e and f). The results indicate that the reduction in FAK expression levels was also accompanied by lower FAK tyrosine phosphorylation.

Cell invasion was linked to FAK accumulation in the lamellipodia [15]. This led to us to determine the cellular localization of phosphotyrosyl-FAK by immunofluorescence using the anti-FAK-p-Y397 antibody. Our results 


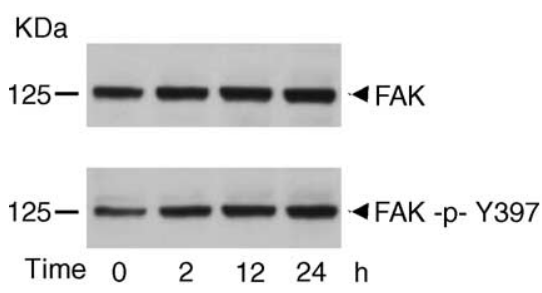

(A) $\quad 100130.2132 .9180 .3 \%$

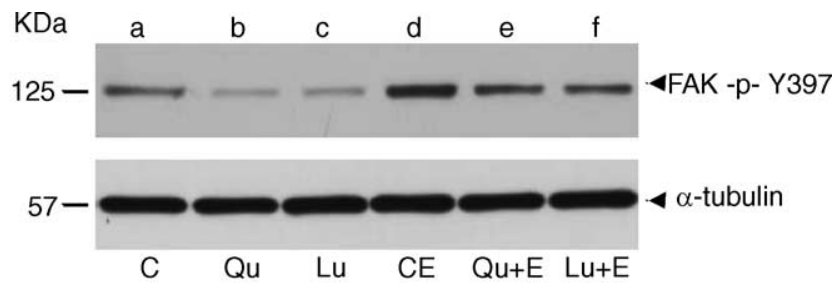

(B) P-FAK $100 \quad 38.0 \quad 47.3 \quad 212.3 \quad 125.0 \quad 120.0 \%$

Fig. 8. Effect of Qu and Lu on basal and EGF-induced FAK expression and tyrosine phosphorylation of FAK in MiaPaCa-2 cells. (A) Cells were treated with $10 \mathrm{nM}$ EGF for 0-24 h. (B) Cells were treated in the absence of (lane a, control) or in the presence of $20 \mu \mathrm{M} \mathrm{Qu} \mathrm{(lane} \mathrm{b),} 20 \mu \mathrm{M} \mathrm{Lu}$ (lane c), $10 \mathrm{nM}$ EGF (lane d) for $24 \mathrm{~h}$. Lanes e and f, MiaPaCa-2 cells first (separate) treated with, respectively, $20 \mu \mathrm{M} \mathrm{Qu}$ and Lu for $24 \mathrm{~h}$, and then were treated with $10 \mathrm{nM}$ EGF for an additional $24 \mathrm{~h}$. At the end of the culture, approximately $4 \times 106$ cells were harvested. Cellular lysates of $50 \mu \mathrm{g}$ of protein were subjected to immunoblotting analyses using anti-FAK antibody (A) and anti-FAK-p-Y397 antibody (B). The equal amount of $\alpha$-tubulin indicates the same protein levels in each lane.

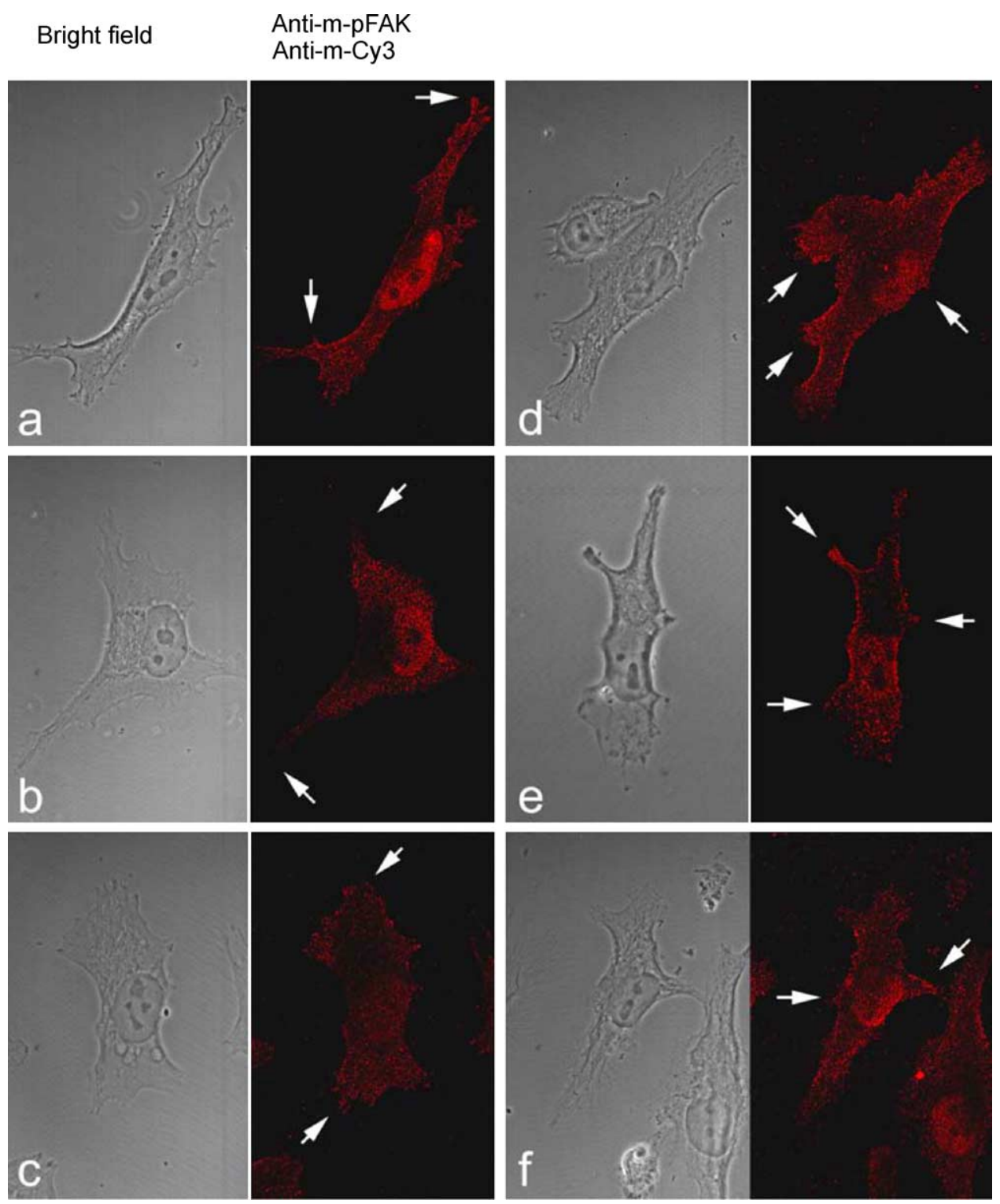

Fig. 9. Effect of Qu, Lu and EGF on phosphotyrosyl-FAK localization in MiaPaCa-2 cells. The cells were plated onto fibronectin-coated coverslips and allowed to grow in the presence of $10 \%$ fetal bovine serum for overnight. Cells were then treated with or without $20 \mu \mathrm{M} \mathrm{Qu}$, Lu and/or $10 \mathrm{nM} \mathrm{EGF}$ for $4 \mathrm{~h}$. The localization of phosphotyrosyl-FAK was then detected by immunofluorescence with mouse anti-FAK-p-Y397 antibody and followed by goat anti-mouseIgG-Cy3. Cells were observed and photographed under fluorescence microscope. Panels: (a) vehicle control; (b) Qu; (c) Lu; (d) EGF; (e) Qu and EGF; (f) Lu and EGF. 
revealed that patches of phosphotyrosyl-FAK-staining were detected around the cell perimeter, cytoplasm and nucleus (Fig. 9a). Interestingly, we observed that EGF elevated the accumulation of phosphotyrosyl-FAK in the lamellipodia (Fig. 9d). Those MiaPaCa-2 cells treated with either Qu or Lu exhibited lower levels of phosphotyrosylFAK distributed within lamellipodia (Fig. 9b and c). To determine if the addition of EGF could rescue the reduced phosphotyrosyl-FAK levels within the lamellipodia caused by $\mathrm{Qu}$ and/or $\mathrm{Lu}$, we treated cells with $20 \mu \mathrm{M}$ Qu or $\mathrm{Lu}$ for $4 \mathrm{~h}$ and then replaced the medium with fresh medium containing only $10 \mathrm{nM}$ EGF. It is worth to noting that significantly higher patches of phosphotyrosyl-FAK-staining were detected around the cell perimeter area (Fig. 9e and $\mathrm{f}$ ). This result supports the idea that phosphotyrosylFAK might play a major role in promoting cell migration.

\section{Discussion}

The targeting of receptor tyrosine kinases to inhibit tumor growth has drawn a great deal of attention in recent years [40]. Flavonoids inhibit the activity of protein tyrosine kinase and the growth of tumor cells with similar potency $[18,25,28]$. Previously we showed that among the flavonoids investigated, $\mathrm{Qu}$ and $\mathrm{Lu}$ were the most potent inhibitors of tumor cell growth and EGFR tyrosine kinase activity $[18,28]$. Our report also indicated that both Qu and $\mathrm{Lu}$ have similar structures, with the same double bond between $\mathrm{C} 2$ and $\mathrm{C} 3$ in ring $\mathrm{C}$, and the same $\mathrm{OH}$ groups on $\mathrm{C}^{\prime}{ }^{\prime}$ and $\mathrm{C}^{\prime}$ in ring $\mathrm{B}$ (Fig. 1). From a structural point of view, we suggest that the double bond between $\mathrm{C} 2$ and $\mathrm{C} 3$ results in ring $\mathrm{B}$ and ring $\mathrm{C}$ being on the same plane, which might be critical for access to the kinase binding site [18]. Currently, we are employing X-ray crystallography of Qu and $\mathrm{Lu}$ co-crystalize with known kinases in order to elucidate the detailed structure-function relation of flavonoids and the ATP binding sites of these enzymes. These results may provide a structural basis for understanding the inhibition mechanism of protein kinases, and will be useful for the further design of specific inhibitors against kinase activity. Our previous results suggest that the flavonoids binding site is placed at or near the ATP binding site of protein kinases [18]. In the present study, our data suggest that $\mathrm{Qu}$ and $\mathrm{Lu}$ exert inhibitory effects on tyrosine and serine/threonine protein kinases (Figs. 2 and 3) via a common mechanism. Further study is needed to determine whether the effects of $\mathrm{Qu}$ and $\mathrm{Lu}$ are restricted to protein tyrosine kinase.

Relating cellular growth response to changes in phosphorylation of cellular proteins in response to a particular tyrosine kinase stimulus like EGF, or an inhibitor like Qu or Lu, has allowed us to discern significant changes in the phosphorylation levels of certain cellular proteins in different tumor cell lines in previous studies $[18,28]$ and in the present study (Fig. 4A). There is now substantial evidence indicating good correlation between the alteration of phosphotyrosyl levels of certain proteins and changes in the extent of cellular proliferation of tumor cells [28,34]. Phosphorylation/dephosphorylation of 170,65 and $60 \mathrm{kDa}$ proteins appears to be the most reliable indicator of cell proliferation in response to EGF, Qu and Lu in A431 cells [28]. In the present study, EGF was found to augment the phosphorylation levels of the $125,110,44 \mathrm{kDa}$ and the aforementioned proteins in MiaPaCa-2 cells (Fig. 4A), while $\mathrm{Qu}$ or $\mathrm{Lu}$ suppressed phosphorylation levels in MiaPaCa-2 cells (Fig. 4A). The cumulative evidence further supports that the 170,65 , and $60 \mathrm{kDa}$ protein substrates are involved in growth messaging. Previously we identified the $170 \mathrm{kDa}$ protein as EGFR. In the present study, we further showed that the $125 \mathrm{kDa}$ phosphotyrosyl protein is FAK. We oberserved that both $\mathrm{Qu}$ and $\mathrm{Lu}$ exhibited strong inhibition of the autophosphorylation of EGFR as well as the transphosphorylation of FAK (Fig. 4A).

Accumulating evidence indicates that FAK plays an important role in the development of human malignances and suggests that increased FAK protein expression and phosphotyrosyl levels in cancer cells correlate with invasive potential [39]. In addition, FAK is important in linking EGFR activation to the cellular machinery that promotes directed cell migration [15,30,41]. In this study, we examined FAK protein expression and relative levels of FAK tyrosine phosphorylation after treatment of MiaPaCa-2 cells with $\mathrm{Qu}, \mathrm{Lu}$ or EGF. Both $\mathrm{Qu}$ and $\mathrm{Lu}$ treated MiaPaCa-2 cells showed a decreased of FAK expression (data not shown), while the EGF stimulation led to an elevated expression of FAK (Fig. 8A). Furthermore, expression of basal and EGF-induced phosphotyrosylFAK (FAK-p-Y397) levels in MiaPaCa-2 cells was also inhibited by both Qu and Lu (Fig. 8B). Our finding that EGF stimulates the phosphorylation of FAK in MiaPaCa-2 cells is in agreement with other study reported by Hsia et al. [15].

The mechanism by which flavonoids affect cell adhesion is not yet clear. Determination of how the flavonoids modulate cell adhesion and migration would aid in the understanding of potential applications of these agents against human tumor proliferation and metastasis. Our data suggests that both $\mathrm{Qu}$ and $\mathrm{Lu}$ inhibit the tyrosine kinase activity of EGFR and also suppress endogenous FAK expression as well (Fig. 8B). Because FAK functions as a key regulator of extracellular matrix-dependent cell migration, and also because endogenous levels of FAK protein expression limit the rate of cell motility, it seems likely that the reduced FAK protein expression and phosphorylation in tumor cells may inhibit cell motility, and in turn, inhibit cell invasion potential $[30,42]$. Our previous and recent works support the concept that $\mathrm{Qu}$ and $\mathrm{Lu}$ represent a group of flavonoids with potential for application as anti-tumor growth and anti-metastasis agents. 
The ability of tumor cells to migrate from the primary tumor to a distal site and invade surrounding tissues is a prerequisite for metastasis. The process of tumor cell invasion relies on several cell properties including actin dynamics, adhesion, motility, and proteolysis. In human A431 carcinoma cells, activation of EGFR was shown to stimulate secretion of MMP-9 and MMP-2, resulting in increased in vitro invasion of this cancer cell line [18]. Both $\mathrm{Qu}$ and $\mathrm{Lu}$ suppressed not only the basal but also EGFinduced invasive activity of the cells [18]. In the present study, we demonstrated that Qu and Lu suppressed not only the basal but also EGF-induced invasive activity in Mia$\mathrm{PaCa}-2$ cells, and that the inhibitory effect of $\mathrm{Qu}$ and $\mathrm{Lu}$ on tumor cell invasion might partially be attributed to the down-regulation of the MMP expression (Fig. 5). Furthermore, limited studies suggest that suppression of the tyrosine phosphorylation may be a mechanism involved in the metastatic process. This hypothesis is supported by the studies which showed that genistein, an EGFR tyrosine kinase inhibitor, could also inhibit the invasion of murine mammary carcinoma cells [43]; and HER-2/neu tyrosine kinase inhibitors suppressed the secretion of gelatinase and invasive potential [8]. Previously, in a parallel study, we demonstrated that activated PTP by [D-Trp6]luteinizing hormone-releasing hormone induced a reduction of cellular protein phosphorylation including EGFR and FAK, and suppressed the invasive activity of tumor cells [44]. These findings suggest that suppression of tyrosine phosphorylation may be involved in tumor metastasis [45]. In the present study, we also found that the inhibition of FAK expression or FAK tyrosine phosphorylation by $\mathrm{Qu}$ and $\mathrm{Lu}$ (Fig. 8) resulted in decreased MMP-9 secretion and the inhibition of MiaPaCa-2 cells in vitro through a reconstituted basement membrane (Fig. 6). This result indicates that FAK signaling may regulate MMP-9 levels, and that MMP activity is required for MiaPaCa-2 cell motility and invasion. Furthermore, our results suggest that cell invasion was linked to the phosphotyrosyl-FAK accumulation in the lamellipodia (Fig. 9).

In conclusion, the results from this study suggest that in human pancreatic carcinoma cells, the antioxidant flavonoids, $\mathrm{Qu}$ and $\mathrm{Lu}$, may act partly through the blockade of the EGFR-signaling pathway leading to growth inhibition and reduced cell invasion/metastasis. Because FAK is elevated in a variety of invasive human tumors, our data suggest that FAK is a promising target for future therapeutic intervention strategies. Qu and $\mathrm{Lu}$ are also potential chemopreventive or chemotherapeutic agents, although much remains to be studied regarding their bioavailability, in vivo disposition and pharmacodynamics.

\section{Acknowledgments}

This work was supported in part by grants from National Science council NSC 88AIA0100193 (M.T.L) and NSC
92-2311-B-001-101 (Y.T.H) and from Academia Sinica (M.T.L.), Taiwan.

\section{References}

[1] Liotta LA, Steeg PS, Stetler-Stevenson WG. Cancer metastasis and angiogenesis: an imbalance of positive and negative regulation. Cell 1991;64:327-36.

[2] Schneider MR, Schirner M. Antimetastatic prostacyclin analog. Drugs Future 1993;18:29-48.

[3] Liabakk NB, Talbot I, Smith RA, Wilkinson K, Balkwill FR. Matrix metalloproteinases 2 (MMP-2) and matrix metalloproteinase 9 (MMP-9) type IV collagenases in colorectal cancer. Cancer Res 1996;56:190-6.

[4] Naylor MS, Stamp GW, Davies BD, Balkwill FR. Expression and activity of MMPs and their regulators in ovarian cancer. Int J Cancer 1994;58:50-6.

[5] Benaud C, Dickson RB, Thompson EW. Roles of the matrix metalloproteinases in mammary gland development and cancer. Breast Cancer Res Treat 1998;50:97-116.

[6] Hua J, Muschel R. Inhibition of matrix metalloproteinase nine expression by a ribozyme blocks metastasis in a rat sarcoma model system. Cancer Res 1996;56:5279-84.

[7] Watson SA, Morris TM, Robinson G, Crimmin MJ, Brown PD, Hardcastle JD. Inhibition of organ invasion by the metalloproteinase inhibitor Batimastat (BB-94) in two human colon carcinoma metastasis models. Cancer Res 1995;55:3629-33.

[8] Zhang L, Lau YK, Xi L, Hong RL, Kim DSHL, Chang CJ, et al. Tyrosine kinase inhibitors, emodin and its derivative repress Her-2/ $n e u$-induced cellular transformation and metastasis-associated properties. Oncogene 1998;16:2855-63.

[9] Llic D, Damsky E, Yamamoto T. Focal adhesion kinase: at the crossroads of a signal transduction. J Cell Sci 1997;110:401-7.

[10] Owens LV, Xu L, Craven RJ, Dent GA, Weiner TM, Kornberg L, et al. Over expression of the focal adhesion kinase (p125FAK) in invasive human tumors. Cancer Res 1995;55:2752-5.

[11] Parsons JT, Martin KH, Slack JK, Taylor JM, Weed SA. Focal adhesion kinase: a regulator of focal adhesion dynamics and cell movement. Oncogene 2000;19:5606-13.

[12] Sieg DJ, Hauck CR, Llic D, Klingbeil CK, Schaefer E, Damsky CH, et al. FAK integrates growth-factor and integrin signals to promote cell migration. Nature Cell Biol 2000;2:249-56.

[13] Tamura M, Gu J, Matsumoto K, Aota SI, Parsons R, Yamada KM. Inhibition of cell migration, spreading, and focal adhesion by tumor suppressor PTEN. Science 1998;280:1614-7.

[14] Gu J, Tamura M, Pankov R, Takino T, Matsumoto K, Yamada KM. Shc and FAK differentially regulate cell motility and directionality modulated by PTEN. J Cell Biol 1999;146:389-404.

[15] Hsia DA, Mitra SK, Hauck CR, Streblow DN, Nelson JA, Ilic D, et al. Differential regulation of cell motility and invasion by FAK. J Cell Biol 2003;160:753-67.

[16] Jones G, Machado Jr J, Merlo A. Loss of focal adhesion kinase (FAK) inhibits epidermal growth factor receptor-dependent migration and induces aggregation of $\mathrm{NH}_{2}$-Terminal FAK in the nuclei of apoptotic glioblastoma cells. Cancer Res 2001;61:4978-81.

[17] Harborne JB. The flavonoids: advances in research since 1980. London: Chapman and Hall, 1998.

[18] Huang YT, Hwang JJ, Lee PPH, Ke FC, Huang JH, Huang CJ, et al. Effects of luteolin and quercetin, inhibitors of tyrosine kinase, on growth and metastasis-associated properties in A431 cells overexpressing epidermal growth factor receptor. Br J Pharmacol 1999;128: 999-1010.

[19] Hertog MGL, Hollom PCH, Katan MB, Kromhout D. Intake of potential anticarcinogenic flavonoids and their determinants in adults in The Netherlands. Nutr Cancer 1995;20:21-9. 
[20] Middleton Jr E, Kandaswami C, Theoharidis TC. The impact of plant flavonoids on mammalian biology: implications for inflammations. Pharmacol Rev 2000;52:673-751.

[21] Kandaswami C, Middleton E, Jr. Flavonoids as antioxidants. In: Shahihi E, editors. Natural antioxidants. Champagne, Illinois: ACS Press, 1997, pp. 174-203.;

Sieg DJ, Hauck CR, Llic D, Klingbeil CK, Schaefer E, Damsky CH, Schlaepfer DD. FAK integrates growth-factor and integrin signals to promote cell migration. Nature Cell Biol 2000;2:249-56.

[22] Kappagoda CT, Karim M, McCormic K, Kandaswami C. Unraveling the French paradox. Chem Innov 2000;30(9):26-31.

[23] Kandaswami C, Perkins E, Soloniuk DS, Drzewiecki G, Middleton Jr E. Antiproliferative effects of citrus flavonoids on a human squamous cell carcinoma in vitro. Cancer Lett 1991;56:147-52.

[24] Constantinou A, Kiguchi K, Huberman E. Induction of differentiation and DNA strand breakage in human HL-60 and K-562 leukemia cells by genistein. Cancer Res 1990;50:2618-24.

[25] Akiyama T, Ishida J, Nakagawa S, Ogawara H, Watanabe S, Itoh N, et al. Genistein, a specific inhibitor of tyrosine kinases. J Biol Chem 1987;262:5592-5.

[26] Sato F, Matsukawa Y, Matsumoto K, Nishino H, Sakai T. Apegenin induces morphological differentiation and $\mathrm{G} 2 / \mathrm{M}$ arrest in rat neuronal cells. Biochem Biophys Res Commun 1994;204:578-84.

[27] Wei YQ, Zhao X, Kariya Y, Fukata H, Teshigawara K, Uchida A. Induction of apoptosis by quercetin: involvement of heat shock protein. Cancer Res 1994;54:4952-7.

[28] Lee LT, Huang YT, Hwang JJ, Lee HPP, Ke FC, Nair MP, et al. Blockade of the epidermal growth factor receptor tyrosine kinase activity by quercetin and luteolin leads to growth inhibition and apoptosis of pancreatic tumor cells. Anticancer Res 2002;22:1615-28.

[29] Weyant MJ, Carothers AM, Dannenberg AJ, Bertagnolli MM. (+)Catechin inhibits tumor formation and suppresses focal adhesion kinase activation in the min/+mouse. Cancer Res 2001;61:118-25.

[30] Lu Z, Jiang G, Blume-Jensen P, Hunter T. Epidermal growth factorinduced tumor cell invasion and metastasis initiated by dephosphorylation and downregulation of focal adhesion kinase. Mol Cell Biol 2001;21:4016-31.

[31] Mosmann TJ. Rapid colorimetric assay for cellular growth and survival: application to proliferation and cytotoxicity. J Immunol Methods 1993;65:55-63.

[32] Samuels ML, Weber MJ, Bishop JM, McMahon M. Conditional transformation of cells and rapid activation of the mitogen-activated protein kinase cascade by an estradiol-dependent human raf- 1 protein kinase. Mol Cell Biol 1993;13:6241-52.

[33] Bradford MM. A rapid and sensitive method for the quantitation of microgram quantities of protein utilizing the protein-dye binding. Anal Biochem 1976;72:248-54.

[34] Lee MT, Liebow C, Kamer A, Schally AV. Effect of epidermal growth factor and analogue of luteinizing hormone releasing hormone and somatostatin on phosphorylation and dephosphorylation of tyrosine residues of specific protein substrates in various tumors. Proc Natl Acad Sci USA 1991;88:1656-60.

[35] Laemmli UK. Cleavage of structural proteins during the assembly of the head of bacteriophage T4a. Nature 1970;227:680-5.

[36] Towbin H, Staehelin T, Gordon J. Electrophoretic transfer of proteins from poly-acrylamide gels to nitrocellular sheets: procedure and some application. Proc Natl Acad Sci USA 1976;76:4350-4.

[37] Heussen C, Dowdle EB. Electrophoretic analysis of plasminogen activators in polyacrylamide gels containing sodium dodecyl sulfate and copolymerized substrate. Anal Biochem 1980;102:196-202.

[38] Saiki KH, Fuji H, Yoneda J, Abe F, Nakajima M, Tsuruo T, et al. Role of aminopeptidase $\mathrm{N}(\mathrm{CD} 13)$ in tumor-cell invasion and extracellular matrix degradation. Int J Cancer 1993;54:137-43.

[39] Sieg DJ, Hauck CR, Schlaepfer DD. Required role of focal adhesion kinases (FAK) for integrin-stimulated cell migration. J Cell Sci 1999; 112:2677-91.

[40] Hunter T. Oncoprotein networks. Cell 1997;88:333-46.

[41] Hauck CR, Hsia DA, Schalaepfer DD. FAK facilitates PDGF-BB stimulated ERK2 activation required for chemotaxis migration of vascular smooth muscle cells. J Biol Chem 2000;275:41092-9.

[42] Kyle E, Neckers L, Takimoto C, Curt G, Bergan R. Genistein-induced apoptosis of prostate cancer cells is preceded by a specific decrease in focal adhesion kinase activity. Mol Pharmacol 1997;51:193-200.

[43] Hauck CR, Sieg DJ, Hsia DA, Loftus JC, Garrde WA, Monia BP, et al. Inhibition of Focal Adhesion kinase expression or activity disrupts epidermal growth factor-stimulated signaling promoting the migration of invasive human carcinoma cells. Cancer Res 2001;61:7079-90.

[44] Scholar EM, Toews ML. Inhibition of invasion of murine mammary carcinoma cells by the tyrosine kinase inhibitor genistein. Cancer Lett 1994;87:159-62.

[45] Liu Y, Kyle E, Lieberman R, Crowell J, Kelloff G, Bergan RC. Focal adhesion kinase (FAK) phosphorylation is not required for genisteininduced FAK- $\beta$-1-integrin complex formation. Clin Exp Meta 2000; 18:203-12. 